part in organising the well-known exhibitions held by that body.

Read received the honour of knighthood in 1912. He was an LL.D. of St. Andrews, was elected to the British Academy in 1913, and had received honours from learned societies in nearly every country in Europe as well as the United States. He was buried at Rapallo.

\section{Mr. T. H. Blakesley.}

Mr. Thomas H. Blakesley died on Feb. 13 at eighty-one years of age. To the older generation of physicists and electrical engineers he was well known. Much of his work has formed the foundations of great practical and theoretical developments which the younger generation accept with but little, if any, thought of the pioneers who initiated researches the results of which are affecting the everyday life of almost every nation.

Blakesley was the son of the Very Rev. J. W. Blakesley, Dean of Lincoln, and was educated at Charterhouse and King's College, Cambridge, where he graduated as a wrangler in 1869 . He first went to Ceylon as an irrigation engineer, and then in 1885 he was appointed instructor in physics and mathematics at the Royal Naval College, Greenwich. In that year Blakesley published his classical work entitled "Papers on Alternating Currents of Electricity." In this treatise he gives many fundamental theorems. In particular, he describes how to measure alternating current power by means of his 'split dynamometer.' He describes fully how phase difference can be determined, and gives for the first time many of those geometrical methods of discussing alternating current problems which are now in everyday use all over the world. $\mathrm{He}$ made valuable contributions also to the mathematical theory of the transmission of electric power by cables and to long distance telephone working. In this connexion he recognised the importance of the hyperbolic functions and computed tables of their numerical values. The value of this work was appreciated by experts at the time, and translations of it were published in Germany, France, and Russia.

Blakesley was also greatly interested in the reform of the teaching of geometrical optics, and used to point out to his friends with great animation the 'absurdity' of some of the definitions of focal lengths, etc., then in vogue at Cambridge. His book on "Geometrical Optics" appeared in 1903. The principles, however, of his proposed reforms in optics he gave in a paper to the Physical Society of London in 1897. His paper to the same Society in 1907 on "Logarithmic Lazy-tongs and Latticeworks" was of a type which would have been much more appreciated by mathematicians of an earlier generation who liked 'mathematical recreations.' His synthetic spectroscope was a colour mixer of a refined type superimposing three homogeneous portions of the spectrum in one picture. An instrument of this type was presented to Finsbury Technical College by the Mercers' Company, of which Blakesley was master in 1902 and 1903 .

Blakesley did good work as honorary secretary of the Physical Society of London for several years. For much of its success and present prosperity the Society is largely indebted to him. He did a great deal to encourage the friendly co-operation of academic lecturers with research physicists employed in industry which is greatly to their common benefit. He will be sadly missed by his friends.

\section{Mr. Abel Chapman.}

SINCE his first work, " Bird Life of the Borders" appeared in 1889, and by its vigour, direct and humorous description, and evidence of close observation, gained the ear of the public, $\mathrm{Mr}$. Chapman published many accounts of his travels, all equally robust and all equally popular. He was a sportsman-naturalist of the best type, as keen to note the ways of his quarry as to secure a trophy, and never likely to be led astray by the theories of professional scientific workers, whom, in a general way, he despised. His own theories, upon such subjects as the migration of birds and protective coloration, he defended with abundant confidence and even obstinacy, but they suffered from a lack of knowledge of the investigations of other workers in the same field.

Mr. Chapman's home at Houxty, in Northumberland, set in the heart of the Border country, afforded him fine opportunities of bird-watching, and his penultimate work, "The Borders and Beyond" (1924), like his earliest, dealt mainly with the natural history problems of his immediate surroundings. But he followed Nature far afield, and his hunting expeditions in Spain, Norway, East Africa, and the Sudan produced a series of interesting books, full of acute observations : "Wild Spain" (1893) and "Unexplored Spain" (1910), "Wild Norway" (1897), "On Safari in British East Africa " (1908), and "Savage Sudan" (1921). In 1896, with Mr. W. J. Buck, he published "The Art of Wildfowling." Only last year his final work appeared, "Retrospect," an autobiographical survey written with the old combativeness and reviewing the more interesting observations of his fifty-four hunting trips and home experiences.

Mr. Chapman was born in 1851 and educated at Rugby. He died at Houxty on Jan. 23, at the ripe age of seventy-seven years.

\section{We regret to announce the following deaths:}

Surgeon-Capt. E. L. Atkinson, D.S.O., parasitologist to Scott's last Antarctic expedition (1910), on Feb. 20, aged forty-six years.

Dr. Harrison G. Dyar, custodian of Lepidoptera in the United States National Museum, a leading authority on American mosquitoes, on Jan. 22, aged sixty-two years.

Mrs. Arabella B. Fisher (née Buckley), secretary for eleven years to Sir Charles Lyell, the geologist, and author of several popular works on general science, on Feb. 9, aged eighty-eight years.

Sir George Fordham, author of numerous papers on archæology, natural history, and other subjects, and of volumes on the history of maps and roadmaking, on Feb. 20, aged seventy-four years.

Commdr. Giovanni Roncagli, honorary secretary general to the Royal Geographical Society of Italy, on Feb. 1, aged seventy-two years.

$$
\text { No. 3096, VoL. 123] }
$$

